\title{
オーステナイト系ステンレス鋼の応力腐食割れに対する陰極防食*
}

北村義治** 森 田茂***

\section{The Cathodic Protection for the Stress-Corrosion Cracking of Austenitic Stainless Steels}

\section{Yoshiharu Kitamura and Shigeru Morita}

As effective methods for preventing the stresscorrosion cracking of austenitic stainless steels, the surface of stainless steel piece was coated with flame-sprayed aluminum or with zinc-rich paint. Stress-corrosion tests were carried out by the constant-strain method and by the constantstress one in 42 percent magnesium chloride solution at $154^{\circ}$. The results showed that the stress-corrosion cracking, immediately followed by the rupture, of the testing specimens whose surface were treated as mentioned above occurred much tardily in comparison with untreated ones.

Further evidence was obtained by measuring the natural electrode potential and the cathodic polarization curves.

\section{1. 緒}

言

応力腐食割れの防止対策としては, 適正な材質の選 定, 装置の設計面からの改善, 応力を除去するための処 置, ショットピーニングなどによる表面加工および腐食 環境の改善などのほかに, 陰極防食法が有効であるとさ れている1 4)。本報は，オーステナイト系ステンレス鋼 の場合について，流電陽極効果を有する表面処理材料に よる陰極防食試験を行ない, 応力腐食割れの防止効果を 明らかにしたものである。

\section{2. 定歪法による試験}

\section{$2 \cdot 1$ 試験装置}

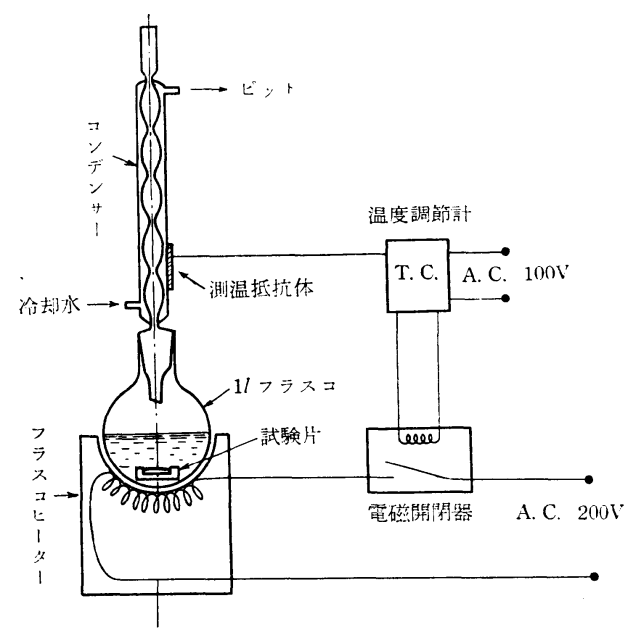

図 1 定歪法試験装置

* 昭和 37 年 10 月 12 日 第 6 回材料試験連合会講演会 (京都)にて発 表

** 味の素(株)中央研究所 (川崎市鈴木町 2,964 )

*** 日本治金工業(株)川崎製造所（川崎市大師河原 7,007)

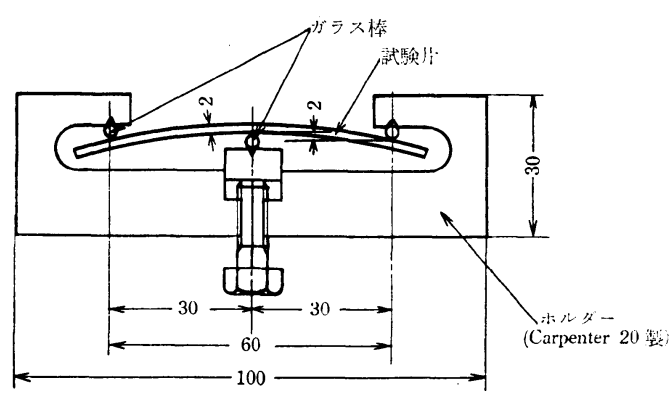

図 2 試験片の保持法

逆流コンデンサー付き $1 l$ 三角フラスコを使用し，そ の概略を図 1 に示した。また, 試験片の保持法は図 2 に 示した。

\section{$2 \cdot 2$ 試験片および試験条件}

試験片の材質は SUS 28 および SUS 33 を用いそ の化学成分を表 1 亿示し, 形状および寸法は図 3 亿示し た。また, 表面は JIS R-6001 $40 \mu$ に仕上げた。試料 の数量は鋼種別に blank および表面処理別のものそれ ぞれ 1 個ずつとした。表面処理材料としては, A1 メタ リコンおよび高濃度亜鉛叙料を用いた。 $\mathrm{Al}$ メタリコン は $\mathrm{Al}$ 純度 $99.99 \%$ のむのを厚さ $0.1 \sim 0.2 \mathrm{~mm}$ に施 乙, 高濃度亜鉛塗料 以上，残部珪酸塩といわれているものを $0.1 \sim 0.2 \mathrm{~mm}$ の厚さに塗布した。

表 1 試験片の化学成分（\%)

\begin{tabular}{l|c|c|c|c|c|c|c|c|c}
\hline \hline 材 質 & $\mathrm{C}$ & $\mathrm{Si}$ & $\mathrm{Mn}$ & $\mathrm{P}$ & $\mathrm{S}$ & $\mathrm{Ni}$ & $\mathrm{Cr}$ & $\mathrm{Mo}$ & $\mathrm{Cu}$ \\
\hline SUS 28 & 0.03 & 0.57 & 1.44 & 0.013 & $\mathbf{0 . 0 1 8}$ & 11.14 & 18.82 & - & - \\
SUSS 33 & 0.03 & 0.69 & 1.46 & $\mathbf{0 . 0 1 4}$ & $\mathbf{0 . 0 2 2}$ & 14.78 & 17.87 & 2.52 & - \\
SUS 27 & 0.06 & 0.71 & 1.70 & 0.024 & 0.015 & $\mathbf{9 . 0 3}$ & 18.46 & - & - \\
\hline
\end{tabular}




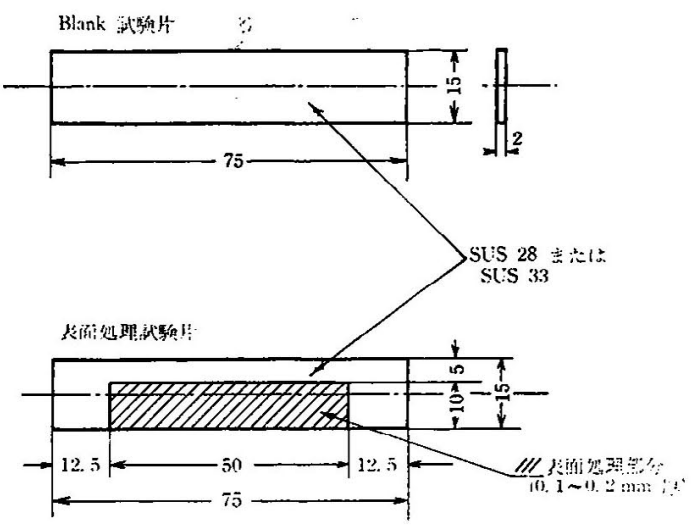

図 3 訊験片の形状，寸法および韭面処理状態

試験液は $42 \% \mathrm{MgCl}_{2}\left(\mathrm{MgCl}_{2}\right.$ は禅蒋 1 級品) 它用い,

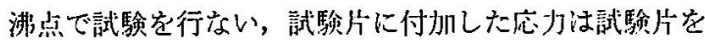
図 2 に示したように塑性領城まで彎四した。

\section{$2 \cdot 3$ 試験結果}

表面処理状態および材貎别の制れ発生時閒を表 2 に示 し，試駼後の試験片外観を写車1に示した。これらより

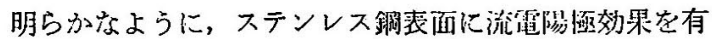

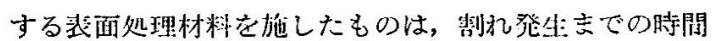
が相当延長されることがわかった。

表 2 表面処理状態别制九発生時間

\begin{tabular}{|c|c|c|c|}
\hline 涌処理状隼 & 槆 & Fit & 制れ発牛時間 \\
\hline blank & $\begin{array}{l}\text { SUS } \\
\text { SUS }\end{array}$ & $\begin{array}{l}28 \\
33\end{array}$ & $\begin{array}{l}2.5 \mathrm{hr} \\
7.0 \mathrm{hr}\end{array}$ \\
\hline 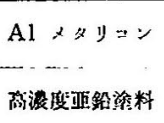 & $\begin{array}{l}\text { SUS } \\
\text { SUS } \\
\text { SUS } \\
\text { SUS }\end{array}$ & $\begin{array}{l}28 \\
33 \\
- \\
28 \\
33\end{array}$ & 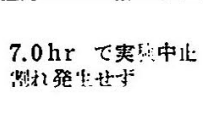 \\
\hline
\end{tabular}

A1 メタリコン

blank
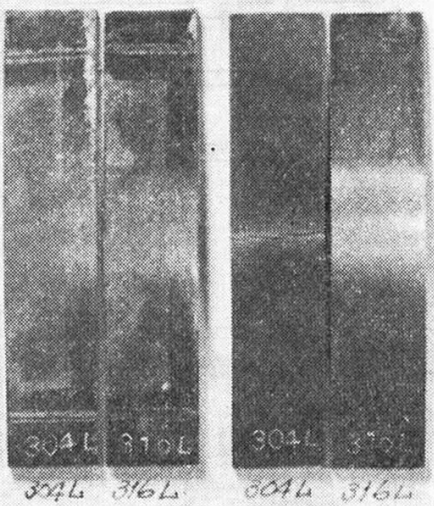

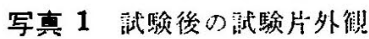

\section{3. 定負荷法による試験}

\section{$3 \cdot 1$ 試験装置}

图 4 および写真 2 に示したような，败火田而 $1,500 \mathrm{~kg}$

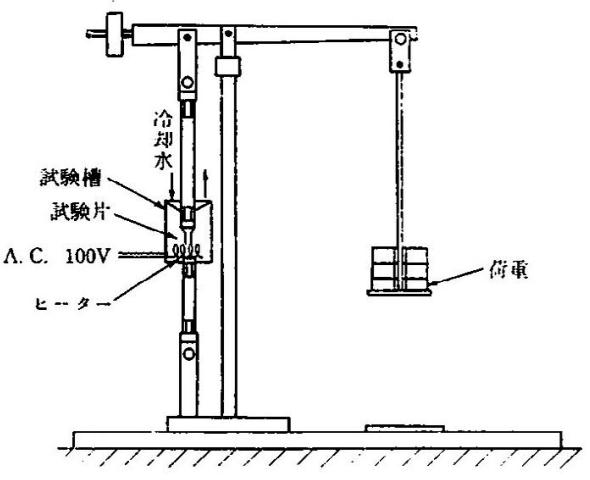

図 4 直接荷重式応力腐食制れ倵駼装置

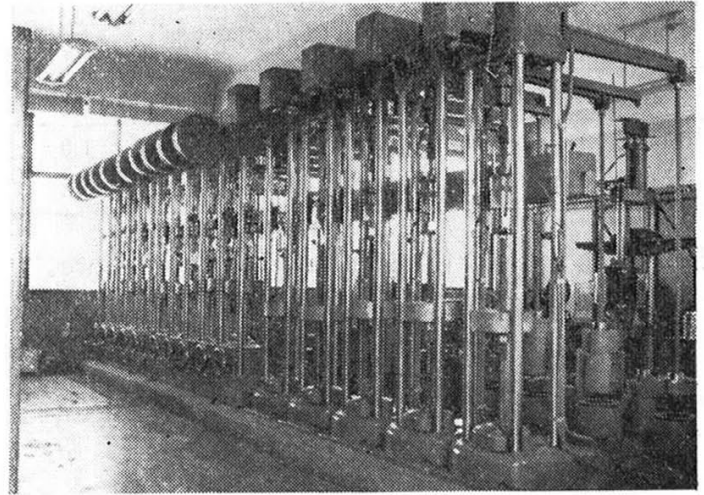

写車 2 直接荷重式応力腐食制れ藏騟装置外観

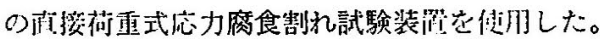

\section{$3 \cdot 2$ 試験片および試験条件}

試験片の材行は SUS 27 を用い，その化学成分は表 1 に示した。また，形状および寸法は図5に示し，表面は JIS R $600140 \mu$ に仕上げた。試䉼の数量は blank お よび装面処理別にそれでれ 2 個ずつとした。なお，表而 処理材料は，2.2 で述べたものと同一のもの空それぞれ $0.1 \sim 0.2 \mathrm{~mm}$ の厚さに施した。

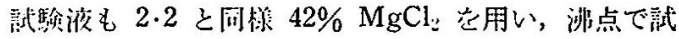
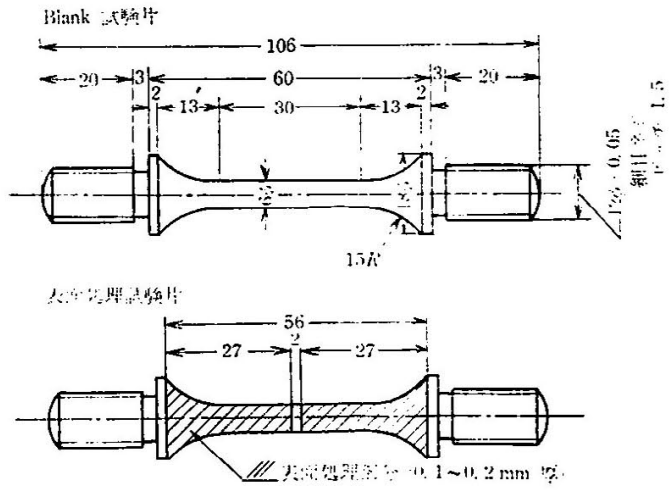

图 5 試験片の形状，寸法脑よび表面処理状態 
blank

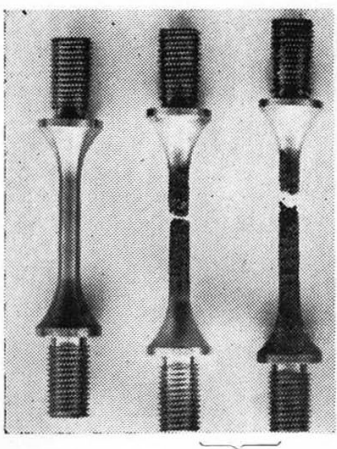

試験前
Al メタリコン

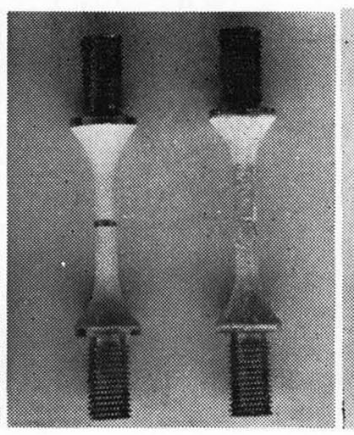

試験前

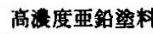

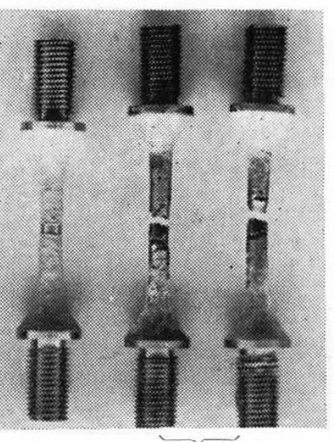

試呀前

試験後

\section{$4 \cdot 2$ 試駼結果}

国 7 に $20 \% \mathrm{NaCl}+1 \% \mathrm{Na}_{2}$ $\mathrm{Cr}_{2} \mathrm{O}_{7} \cdot 2 \mathrm{H}_{2} \mathrm{O}$ 水溶液に対する 各試料の自然電極電位測定結果 を示した。これらの結果より， それぞれの電位は約 2 時間程度 でほほ一定の安定した電位とな る。ステンレス鋼に Al メタリ コンまたは高濃度覀鉛塗料を施 した試料は,これら表面処理材 料のみの電位にごく近い值をと ることが明らかとなった。この ことから，ステンレス鋼-Al メタリコン系およびステン レス鋼一高濃度亜鉛塗料系の分極特性はほとえど完全に 近い陰極支配であることが想定される。

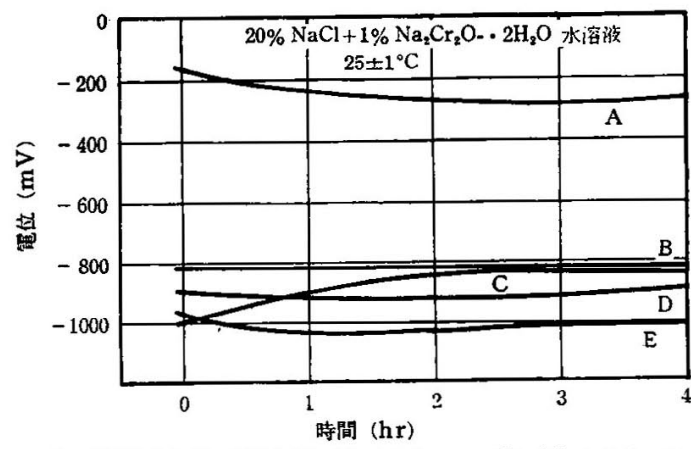

A: SUS 27 B: SUS 27-A1 くタリコン C: A1 イタリコン

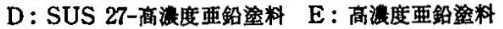

図 7 自然電極電位測定結果 (SCE 基洮)

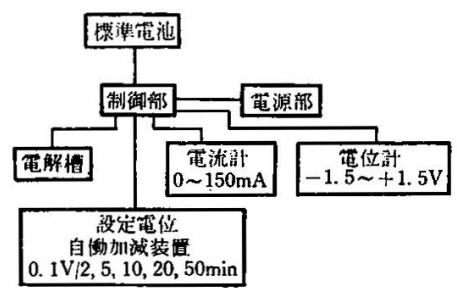

図 8 ポテンショスタットのプロックダイヤグラム

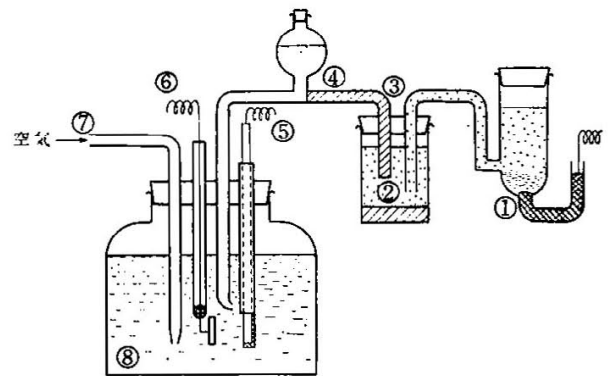

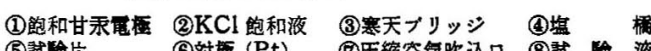
(5)試殓片

図 9 電解槽 


\section{5. 陰分極曲線の測定}

\section{$5 \cdot 1$ 試験装置}

試験装置注ポテンショスタット（日亜計器 $\mathrm{N}-\mathrm{FP}_{2}$ 型） を使用し，そのブロックダイヤグラムを図 8 にままた， 電解槽を図9 亿示した。

\section{$5 \cdot 2$ 試験片および試験条件}

試験片は SUS 28 , SUS 28 の試験片表面露出部の全 面に $\mathrm{Al}$ メタリコンを施したものおよび同表面露出部の 一部に $\mathrm{A} 1$ メタリコンを施したものを用い, 図 10 にこ れら試験片の形状および寸法を示した。

なお，試験液は 4.1 と同一とした。

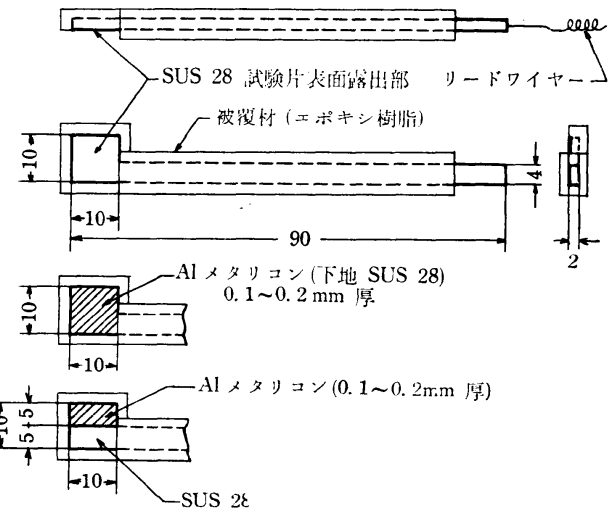

図 10 試験片の形状および寸法

\section{$5 \cdot 3$ 試 験 結 果}

各試料の陰分極曲線測定結果を図 11 亿示した。図中 A，C 点は Al メタリコンおよび SUS 28 の表面の一 部に $\mathrm{Al}$ メタリコンを施したものの自然電極電位であ る。図 7 および図 11 上り，ステンレス鋼- $\mathrm{Al}$ メタリコ ン電極系の分㥛特性は注とえど完全な陰極支配であると 考えられるから，C点を通り横軸に平行に引いた線と，

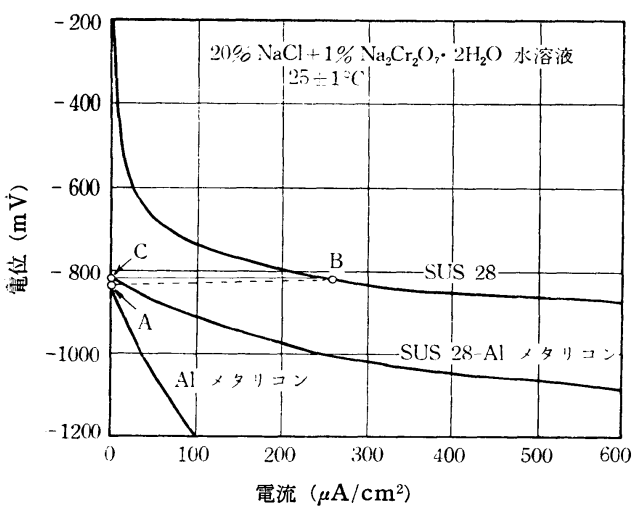

図 11 陰分極曲線測定結果 (SCE 基準)
SUS 28 の陰分極曲線との交点を B と寺れば，A，B 点 を結んだ線は $\mathrm{A} 1$ メタリコンの陽分極曲線となり， $\mathrm{B}$ 点 亿相当する電流は SUS 28 の防食電流を示す。

\section{6. 考察}

定歪法および定負荷法による応力腐食制れ試験結果上 り，流電陽極効果を有する表面処理材料をステンレス鋼 の表面に施すことは，割れ防止に有効であると考える。 本試験条件下では，試験中 $\mathrm{A} 1$ メタリコンまたは高濃度 亜鉛涂料の部分的な涂離または溶出が認められ，それが 㓶れ発生時間また注破断時間を決定ゔける結 果となっ た。筆者らは, これら表面処理材料の制離防止のため, 下地に Mo また注 METOCO No. $40 \mathrm{C}(80 \% \mathrm{Ni}, 20 \%$ Cr）の金属溶射を行ない，その上に $\mathrm{Al}$ メ.タリコンまた

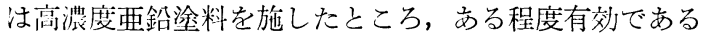
ことを確認した。また，図７に示した自然電極電位およ び図 11 に示した陰分極曲線測定結果より，表面処理材 料を施した試料は十分に㓌極防食の效果を期待しうるる のと考える。

\section{7. 結言}

オーステナイト系ステンレス鋼の応力腐食割れの防止 対策の一つとして, $\mathrm{Al}$ メタリコン, 高濃度覀鉛整料な ぞの適用は，すぐれた効果のあるものと考える。特に実 装置環境に㧈いては, 本試験条件より mild な場合が多 く，そのため付着陽㥛材料の溶出または涂離訬なくそ の寿命は延長され, 本試験の結果よりさらに良好な成績 が期待される。筆者らはさきに, 温度が常温から $100^{\circ} \mathrm{C}$ で $\mathrm{NaCl} 0.2 \%\left(\mathrm{Cl}^{-} 1,300 \mathrm{ppm}\right)$ を含むアミノ酸類水 溶液環境で使用した SUS 27 製熱交換器へッダーが, 使用時間約 5,000 時間で応力腐食㓶犯を起こしたことを

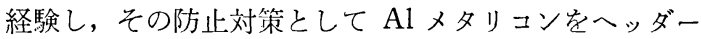
に施し，約 1 年経過したが割れの発生をみず，すぐれた 成果をおさめている。

なお，防食効果を向上させるため， $\mathrm{Mg} ， \mathrm{Al}$ または Zn を主体とした陰極防食用流電陽極合金を用いたメ夕 リコンの場合などに関し，引き続き実験を進めている。

本実験の実施にあたり，日本治金工業株式会社川崎製 造所川畑正夫副所長, 味の素株式会社中央研究所岡野一 良第 3 研究部長よりご愁篤なるご指導を賜わり，ここに 哀心より謝意を表する。（昭和 38 年 3 月 6 日受理）

\section{文献}

1) H. R. Copson: Corrosion, 10, 124 (1954)

2) H. H. Uhlig \& J. Lincoln: J. Electrochem. Soc., 105, 325 (1958)

3) T.P. Hoar \& J. G. Hines: J. Iron Steel Inst., 182, 124 (1956) ; 184, 166 (1956)

4) W. G. Renshaw: Corrosion, 12, 477 (1956) 


\title{
Der kathodische Schutz vor dem Beanspruchung-Korrosion- Spalt der austenitischen nichtrostenden Stähle
}

\author{
Yoshiharu Kitamura und Shigeru Morita
}

Ein effektiver Schutz der austenitischen nichtrostenden Stähle vor dem Beanspruchung-KorrosionSpalt besteht darin, dass die Oberfläche des nichtrostenden Stahles mit Aluminium-Metallspritzen oder mit zinkreichem Anstrich bedeckt ist.

Das Ergebnis der Beanspruchung-Korrosion-Prüfung, sowohl bei konstanter Belastung als bei konstanter Beanspruchung in 42 prozentiger $\mathrm{MgCl}_{2}$ Lösung bei $154^{\circ}$ zeigen eine deutliche Verzögerung des Beanspruchung-Korrosion-Spalt der nichtrostenden Stahl-Probe, deren Oberflache wie oben geschrieben bedeckt sind, in Vergleich mit unbedeckter Probe.

Die Effecktivitàt des Korrosion-Schutz der austenitischen nichtrostenden Stahle mit Aluminium oder Zink wird auch mittels der Ermittlung der natürlichen Elektrodenpotentiale und der kathodischen Polarisations-Kurven bestgestellt.

\section{塗装塗膜の断面をみる一方法 \\ A Preparation Method of Cross Section of Painted Steel for Microscopic Observation}

青木敬雄*岛田実*

Keio Aoki and Minoru Shimada

It is important for us to observe the cross sections of painted steels in the study of anticorrosive coatings. But it is not easy task to prepare the cross sections of painted steels.
We found an improved method to prepare the cross sections, and obtained many knowledges and useful microphotographs.

\section{1. ま えがき}

塗装鋼板を切断して，その断面の椂子を観察すると， 塗装についての興味ある事実をみることができる。たと えば, 塗料の塗り重祆の㥞子, 被塗面の凹凸への塗料の なじみ具合，あるいは塗装に生じたフクレ，錆などの欠 陷を立体的に観察することができる。

しかしながら，叙装鋼板の断面を観察することは，切 断や研摩のときに塗膜を傷め易く，容易ではない。その ためか，乙れを塗料の試験や研究の手段として実際的に 応用した例をいままてにあまりみない。たら゙鉄䇴を用い た塗装断面の観察例が報告されている1)。

筆者らは，水圧鉄管塗装の研究を進めるうえて，凹凸 の激しい被塗面に起こる叙装の問題点を明らかにするた め, この “塗装断面の観察”を実際的な手段として用い た。その結果，塗装鋼板の断面を観察することは，いま まで考えられていたほど困難なことではなく，切断した 塗装鋼板の断面を一定の研摩方法で磨くことによって手 軽に行なえることがわかった。この方法による塗装塗膜

* 電力中央研究所技術研究所 (東京都北多摩郡狛江町)
の観察は, 多方面に応用が考光られるので, その詳細に ついて報告する（写真 1 )。

\section{$2 \cdot 1$ 試片の作り方}

\section{2. 断面の観察方法}

断面観察をする叙装鋼板(とくに厚さの制限はないが, $3 \mathrm{~mm}$ 厚程度のものを用いるのが，切断のときに容易で ある) は，切断の前に，あらかじめその個所を含めてエ ポキシ樹脂接着唷などで $3 \mathrm{~mm}$ 厚ほどに塗装面を覆っ ておく。これによって，切断や研摩のときに塗膜がはが れ落ちたり，傷つけられたりするの荌防ぐことができ る。数 $100 \mu$ の膜厚に及ぶライニング塗装面などでは, とくにこの処置をする必要はない。塗装面を覆った樹脂 が十分に硬化してから，こ礼を金銛で切断する。このま 〉では面が非常に粗いので，まず細目の平ヤスリで研摩 して，金鋸によって生じた凹凸を平滑にする。このあと に 320 番と 600 番の 2 種の研摩紙を用いて粗さの順に研 摩する。このとき，次にあげるような点に注意しながら 研摩を進める。

平ヤスリのときも, 研摩紙の場合も, 研摩の方向常 